\title{
Publisher Correction: Charge radii of exotic potassium isotopes challenge nuclear theory and the magic character of $N=32$
}

Á. Koszorús, X. F. Yang (D), W. G. Jiang (D), S. J. Novario, S. W. Bai, J. Billowes, C. L. Binnersley, M. L. Bissell, T. E. Cocolios (D), B. S. Cooper, R. P. de Groote, A. Ekström, K. T. Flanagan, C. Forssén (D), S. Franchoo, R. F. Garcia Ruiz DiD, F. P. Gustafsson (D), G. Hagen (D), G. R. Jansen (D), A. Kanellakopoulos (D), M. Kortelainen (D), W. Nazarewicz (D), G. Neyens (D), T. Papenbrock (D), P.-G. Reinhard (D), C. M. Ricketts (D), B. K. Sahoo (D), A. R. Vernon (D) and S. G. Wilkins (D)

Correction to: Nature Physics https://doi.org/10.1038/s41567-020-01136-5, published online 28 January 2021.

This Letter was originally published online incorrectly without open access, whereas it is actually covered by an Open Access licence (CC BY 4.0). The copyright line in the PDF mistakenly read “ The Author(s), under an exclusive licence to Springer Nature Limited 2020” but should have been '(C) The Author(s) 2021'. Furthermore, Extended Data Table 1 was missing from the online PDF. These errors have now been amended in all versions of the Letter.

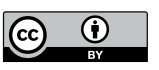

Open Access This article is licensed under a Creative Commons Attribution 4.0 International License, which permits use, sharing, adaptation, distribution and reproduction in any medium or format, as long as you give appropriate credit to the original author(s) and the source, provide a link to the Creative Commons license, and indicate if changes were made. The images or other third party material in this article are included in the article's Creative Commons license, unless indicated otherwise in a credit line to the material. If material is not included in the article's Creative Commons license and your intended use is not permitted by statutory regulation or exceeds the permitted use, you will need to obtain permission directly from the copyright holder. To view a copy of this license, visit http://creativecommons.org/licenses/ by $/ 4.0 /$.

Published online: 24 February 2021

https://doi.org/10.1038/s41567-021-01192-5

(C) The Author(s) 2021 